This item was submitted to Loughborough's Research Repository by the author.

Items in Figshare are protected by copyright, with all rights reserved, unless otherwise indicated.

\title{
Examining the interplay of career, migration and national cultural identity: the case of Indian scientists
}

PLEASE CITE THE PUBLISHED VERSION

http://dx.doi.org/10.1111/j.1468-2435.2012.00768.x

PUBLISHER

Wiley / @ The authors. Journal @ International Organization for Migration

VERSION

AM (Accepted Manuscript)

LICENCE

CC BY-NC-ND 4.0

\section{REPOSITORY RECORD}

Cohen, Laurie, Joanne Duberley, and M.N. Ravishankar. 2019. "Examining the Interplay of Career, Migration and National Cultural Identity: The Case of Indian Scientists". figshare. https://hdl.handle.net/2134/18467. 


\title{
Examining the Interplay of Career, Migration and National Cultural Identity: The Case of Indian Scientists
}

\author{
Laurie Cohen Joanne Duberley and M.N. Ravishankar
}

\begin{abstract}
In this paper, we examine individuals' career migration across international borders. It is widely recognized that globalization has fundamental implications for the careers of people across geographical and cultural boundaries. However, our understanding of the interplay of migration, career development and national/cultural identities remains undeveloped within the extant literature. In this paper, we seek to offer insights into this relationship. Focusing on Indian scientists, an occupational group whose careers have long been associated with movement around the world, in this paper we examine these issues. Empirically, we examine three themes: why Indian scientists see international mobility as important in the development of their careers; continued links with India; and the interplay of national /cultural affiliation and respondents' career experiences. In light of our findings, in the discussion section we argue that considering Indian scientists as a career diaspora highlights three important features that in the main have received only limited attention in the extant literature: career as a social form and process; the notion of the scientific career as a cultural product; and the interrelationship of career and national /cultural affiliation as ongoing facets of individuals' identities as they develop diasporic careers.
\end{abstract}

\section{INTRODUCTION}

In this paper, we examine individuals' career migration across international borders. It is widely recognized that globalization has fundamental implications for the careers of people across geographical and cultural boundaries (Baruch et al., 2007; Iredale, 2001; Pieperl and Jonsen, 2007). However, our understanding of the interplay of migration, career development and national / cultural identities remains undeveloped within the extant literature. In this paper, we seek to offer insights into this relationship.

The forms of what we might call "career migration", are many and varied, triggered by the convergence of a wide range of economic, political, sociocultural and individual circumstances (Ackers and Gill, 2008; Carr et al., 2005). In the broadest s e n s e, distinctions have been made between voluntary and forced career migration, where the former includes people who, acting either as individuals or with organizational sponsorship, choose to develop their careers outside of their country of origin. Alternatively, by forced migration we are referring to asylum seekers and refugees who flee their countries at times of crisis. However, migration scholars have highlighted the limitations of this distinction and the increasing blurring of these conceptual boundaries (King, 2002).

In the careers field, the focus has tended to be upon highly agentic, skilled career migrants. Scholars have developed our understandings of some forms of migration (Carr et al., 2005; Dickmann and Harris, 2005) and our insights into the experiences of certain migrant groups, most notably corporate expatriates (Collings et al., 2007). However, important gaps exist within the existing careers literature. In particular, little has been written about issues such as the significance of migrants' country of origin for their career thinking and 
enactment, or of the relationship between country of origin and host country (which often involves a move from a less to a more economically developed country). Further- more, although scholars have become increasingly interested in career identity, the relation- ship between career development and national / cultural identity remains unexamined. Such considerations are likely to have a significant impact on individuals' experiences of international career migration.

To investigate these questions, in this paper we focus on Indian scientists, an occupational group whose careers have long been associated with movement around the world (Kapur, 2004). Research scientists could be seen as highly mobile, professional career migrants, but typically without specific corporate sponsorship. In this sense, they resonate with the cohorts studied by Carr and his colleagues (2005) and Ackers and Gill (2008). However, the Indian context also contains other notable features that make it an illuminating and rich backdrop for our case study. Since the 1950s, many Indian research scientists have migrated to North America and Europe to start and further their careers in universities and research laboratories. This migration has led to numerous debates about the "brain drain" of scientists to the West and the resulting debilitating impact on the science and technology sector in India (Ackers, 2005). Investigations into the triggers for the large-scale migration and movement of Indian scientists have pointed to the limited job opportunities for scientists in India, to the inability of leading Indian research institutions to attract talented individuals, and to the long-standing perception that the monetary rewards on offer to a research scientist in India pale significantly in comparison with global standards (Balram, 2001). On the other hand, recent accounts in the popular media note that the advantages of mobility are often tempered by a series of important questions that scientists face in relation to their sense of cultural identity and national affiliation. It is also worthwhile noting that the migration of Indian research scientists has gained further pace since the radical liberalization of India's economy from the early 1990s onwards. Indeed, with respect to global career opportunities, this increased interaction with the Western world has opened up a whole new landscape for talented Indian research scientists (Nilekani, 2008). In short, while amongst career scholars there is an emerging consensus that career migration is becoming a worldwide phenomenon (Pieperl and Jonsen, 2007), because of Indian scientists' long-standing experiences with migration and their increasing mobility in India's new economy, questions about the consequences of migration for careers are especially pertinent, and in both the academic press and the popular media they emerge in sharp relief (D’Mello and Sahay, 2007; Narasimha, 2008; Raghuram, 2004).

Following this introduction, we review contributions to the literature on career mobility and diaspora, examining their potential to offer more socially and culturally nuanced under- standings of international career movement. Next, the empirical section focuses on three permeating themes: why Indian scientists see international mobility as a priority in the development of their careers; continued links with India; and the interplay of national /cultural affiliation and respondents' career experiences. Finally, in light of our findings, in the discussion section we argue that considering Indian scientists as a career diaspora high- lights three important features that in the main have received only limited attention in the extant literature: career as a social form and process; the notion of the scientific career as a cultural product, significantly shaped by people's migration experiences; and the interrelation- ship of career and national/cultural affiliation as ongoing facets of individuals' identities as they develop diasporic careers.

\section{CAREER MOBILITY AND THE MIGRATION OF INDIAN SCIENTISTS}

It is widely recognized that changes in international political and economic contexts coupled with technological advances have resulted in a specialization of skills and competences such that highly skilled people are in growing demand and are recruited on a global basis (King, 2002; Mahroum, 2001). Since the 1960s, the idea of "brain drain"' has been central to the 
career migration literature (Ackers, 2005), and has been used in particular to describe the movement of highly skilled workers across national /cultural borders.

The brain drain metaphor is of course very negative, connoting images of wastage and depletion, and typically used to describe a process that is unidirectional: a poor country being emptied of its knowledge base as a rich country is filled (Ackers, 2005; Varma, 2007). However, in the past decade this view has been widely contested (Williams et al., 2004). With respect to science in particular, Varma argues that the unidirectional flow of knowledge suggested by brain drain does not take account of the nature of scientific research, which is characteristically undertaken in international teams across national /cultural boundaries, and disseminated on a global basis (see also Ackers and Gill, 2008).

The concept of "brain circulation"' has been used by migration scholars (Meyer, 2001; Singhal and Rogers, 2001; Varma, 2007) to capture this more complex and dynamic set of processes. Notably, whereas the brain drain metaphor has connotations of permanence, circulation draws our attention to movement as the norm. In the careers field, expressing much the same idea, Carr et al. (2005) propose the term "talent flow" in an attempt to move beyond the scientific and technological spheres to include business and management more generally. Here, an interesting feature, identified by both Ackers (2005) and Varma (2007), is how technology further enables knowledge circulation, such that the movement of knowledge is of course no longer dependent on an individual's physical presence.

While we agree that the metaphors of talent flow and brain circulation do appear to overcome some of the limitations of brain drain, they nevertheless raise other concerns. In particular, we would take issue with their excessive voluntarism, and the lack of attention to the social and cultural contexts in which people work and seek to progress their careers. To explore these issues further, we turn to the concept of diaspora.

\section{INSIGHTS FROM THE DIASPORA LITERATURE: PATTERNS OF MOVEMENT, IDENTITIES AND CULTURAL PRODUCTION}

Given the long tradition of Indian scientists moving around the globe to further their careers, the concept of diaspora offers potential insight into their experiences. The term "diaspora" refers to the dispersion of people from their homeland. Initially, diaspora studies concentrated on what have been termed "victim" diasporas (Cohen, 1997, 2008), those that suffered forced dispersal following a traumatic event, with the Jewish Diaspora being a major focus for study. However, the increased movement of populations across the globe has lead to a recognition of the complex variety of political, economic and cultural factors (Brah, 1996) that create patterns of migration. Thus the term is often used in the current context to refer to any group that is considered transnational (Vertovec, 1997), and recent theorizations have sought to provide more expansive definitions that can cover a broad range of groups, whether their movement was considered to be voluntary or involuntary (Koshy and Radhakrishnan, 2008). Central to much diaspora theory is a strong and active myth of return to the home country. Indeed, Koshy and Radhakrishnan (2008) argue that to many commentators, this myth of return is seen as is a precondition of a robust diaspora.

More recently, diaspora scholars have turned their attention from a primary focus on structural considerations and patterns of movement to a wider consideration of cultural features and consequences. King (2002) explains that while in the past there were two distinct strands of enquiry - one focusing on the "act" of migration and the other on its "products" - the overlaps between these strands are becoming increasingly apparent and researchers have begun to explore their interplay. We see this more expansive conceptualization as particularly relevant to questions of career thinking and enactment. From this perspective, Vertovec delineates three different meanings of diaspora: diaspora as a social form, a mode of cultural production and as a type of consciousness (Vertovec, 1997: 278). First, diaspora as a social form concerns an identified group characterized by a "triadic relationship" between (a) glob- 
ally dispersed yet collectively self-identified ethnic groups, (b) the territorial states and contexts in which such groups reside and (c) the homeland states and contexts from which they or their forebears came. As noted above, within the diaspora literature, this has been the dominant approach (Cohen, 1997, 2008).

With respect to this conceptualization, Indian research scientists are significant. Koshy and Radhakrishnan (2008) explain that contemporary South Asian diasporas are important groups to study, as they are embedded in the three major forces that have shaped global modernity: capitalism, colonialism and nationalism. They propose that in contrast to diaspora theory, in which the myth of return is seen as a defining characteristic, for this group the issue of return is open to question. Indeed, they argue that in the South Asian case the opposite can be true - a weak myth of return can coexist with and foster a strong diaspora (Koshy and Radhakrishnan, 2008: 8). King too suggests that this myth has become increasingly problematic in the current context, taking issue with the increasingly outdated dichotomies that underpin it: "permanent" versus “temporary", "home” versus "somewhere else”. As he puts it: "Members of transnational communities may feel 'at home' in two or more places (or not feel at home anywhere)”' (King, 2002: 102). Ackers and Gill’s study of research scientists adds another important twist to this debate. They highlight how host countries, having invested heavily in migrant scientists' training, are reluctant to lose them just at the point at which they are becoming really productive and so develop strategies to "lock them in'” (Ackers and Gill, 2008: 17). Considering Indian scientists' careers in light of these debates thus raises important issues about whether scientists see themselves as "free agents" or as situated within career communities, their use of ethnically orientated networks in choosing where to go and, once they have moved abroad, the nature of the links they seek to establish with their country of origin and their host countries.

Second, viewing diaspora as a mode of cultural production concerns "the world-wide flow of cultural objects, images and meanings resulting in variegated process[es] of creolization, back and forth transferences, mutual influences, new contestations, negotiations and constant transformations"' (Vertovec, 1997: 19). From this perspective, diaspora involves a constant interchange of products, symbols and meanings across borders (King, 2002). Kapur (2004) vividly illustrates this point, highlighting the influential role played by international migration and India's diaspora in the country's intellectual, cultural, economic and political life. In her view, not only is there a constant flow of ideas between countries of origin and host countries, but the role played by India's non-resident communities in the circulation of knowledge has been a characteristic of Indian life since before Independence. Speaking about scientists more generally, Ackers and Gill (2008) likewise highlight the important contribution that "intellectual diasporic networks" (Meyer, 2001) can make to their countries of origin. For us, this perspective leads to important, highly pertinent questions about how scientists' career mobility impacts on the science they do and with what consequences, both for the countries in which they settle and for India.

Finally, Vertovec proposes that diaspora can be considered as a type of consciousness, a particular awareness that is said to be generated among contemporary transnational communities. Here, in common with many other diasporic scholars, instead of "consciousness" we will use the term "identity" to draw attention to a concept that is not fixed or static but, rather, is an ongoing process and set of allegiances, "situated in the flow of time" (Wodak et al., 1999: 11) and space. From this perspective, diasporic identities are seen to be paradoxi- cal, as Glick Schiller et al. (1996: 11) highlight: "with their complex web of social relations transmigrants draw upon and create fluid and multiple identities grounded both in their soci- ety of origin and their host societies'. Whilst Benet-Martinez and her colleagues (2002) found that for some people these different identities can be a potential source of conflict, more recent research has highlighted the virtues of retaining a diasporic identity and the creativity that this promotes (Cohen, 2008). This view of diaspora elucidates the complex relationship between career mobility and national/cultural identity, a relationship that has received little research attention.

In the management field, the literature on globalization and transnationalism has tended to 
play down the role of diaspora and debate has focused on cosmopolitanism (e.g. Florida, 2004; Kanter, 1995). Anderson (2001) argues that cosmopolitans distance the self from all "parochialisms emanating from allegiances to nation race or ethnos"' (p. 267), favouring an ideal of world citizenship and weak national affiliations. Similarly, Halsall (2009) suggests that in management writing the ability to transcend place is a key feature of cosmopolitanism. This involves the development of a mindset in which place becomes irrelevant, and of portable skills that transcend national /cultural boundaries.

Here, Indian scientists provide a compelling empirical example. In Koshy and Radhakrishnan's view, "the most striking feature of South Asian diasporas, and one which holds the greatest potential for discussions of cosmopolitanism today, is the extraordinary heterogeneity of South Asian identity that has historically enabled the maintenance of multiple and simultaneous modes of belonging" (Koshy and Radhakrishnan, 2008: 12). Thus a complex relationship exists between diasporic and cosmopolitan identities. Ballard and Pardesh (1994) use the concept of "adaptive strategies" to examine how different South Asian groups in the United Kingdom (UK) follow their own distinctive dynamics. In particular, they highlight individuals' capacity to be multicultural. They compare this to being bilingual, arguing that people can develop the competence to behave appropriately in a number of different arenas, and to switch codes as appropriate. An important element of this research will be to examine research scientists' national/cultural affiliations and their impact on career decision-making and enactment.

In light of this review, our empirical analysis focuses on these questions:

1. How do Indian scientists account for their decisions to go abroad to pursue their careers?

2. How do relationships with India feature in respondents' talk about career development?

3. How are Indian national /cultural identity commitments reflected in respondents' career accounts?

\section{RESEARCH DESIGN}

This paper is based on the accounts of 26 Indian scientists based in India and the UK. These scientists were all conducting research in what would be classed as science, engineering and technology subjects. Given the historical relationship between the two countries and the UK's scientific reputation, the UK has long been a favoured destination for Indian scientists seeking overseas positions.

Scientists work in a variety of organizational contexts and sectors, including public-sector institutes and universities and private-sector companies; indeed, our previous research (Duberley et al., 2007) highlighted the diversity of scientific career patterns and the dynamism within a single individual's career trajectory. This study is no exception. At the time of interview, 16 respondents were based in India, at three prestigious public-sector scientific institutions; nine of these had full-time, permanent positions, while seven were $\mathrm{PhD}$ students. Amongst the ten UK-based respondents, eight had permanent posts within university departments, one was working as a nanotechnology scientist in a private-sector R\&D company and one was a PhD student. Notably, while we only had a single-private sectorbased employee in our sample, 14 respondents had previously worked in industry and 13 maintained ongoing industrial c ollaborations. Likewise, the nanotechnology scientist in the R\&D company had ongoing collaborations with his previous university. As Tables 1-3 show, there was significant variety in the career paths of this group. It is evident that although moves across international boundaries were common, it would be hard to distinguish those who had settled in one place from those who were likely to continue to move. As Ackers and Gill (2008: 12) point out, the traditional distinction between 
permanent "migration" and more temporary forms of "mobility" now holds little validity and may actually constrain our understanding of this phenomenon (Iredale and Appleyard, 2001).

Respondents were recruited via a combination of purposeful and snowball sampling (Cassell and Symon, 2004) and interviewed over a 6-month period in 2008. Our sample included scientists at early, middle and later career stages. The India cohort included PhD students who were only just starting out, in order for us to compare how conceptions of career may have changed with India's changing economic climate.

TABLE 1

RESEARCH PARTICIPANTS (LATE CAREER)

\begin{tabular}{|c|c|c|c|}
\hline Respondent & Discipline & Age/gender & Position \\
\hline Hari & Aerospace & $55 / M$ & Professor, research institute, India \\
\hline Mina & Molecular biology and genetics & $60 / \mathrm{M}$ & Professor, research institute, India \\
\hline Kirit & Solid state and structural chemistry & $60 / \mathrm{M}$ & Professor, research institute, India \\
\hline Samir & Physics & $50-60 / \mathrm{M}$ & University professor, UK \\
\hline Ravi & Aerospace & $60 / \mathrm{M}$ & Professor, research institute, India \\
\hline Sanj & Materials & Late $40 \mathrm{~s} / \mathrm{M}$ & University professor, UK \\
\hline Rajan & Materials & Early $60 \mathrm{~s} / \mathrm{M}$ & University professor, UK \\
\hline Sunil & Medical science & Late $50 \mathrm{~s} / \mathrm{M}$ & University professor, UK \\
\hline Sameer & Engineering & Early $60 \mathrm{~s} / \mathrm{M}$ & University professor, UK \\
\hline
\end{tabular}

TABLE 2

RESEARCH PARTICIPANTS (MID-CAREER)

\begin{tabular}{|c|c|c|c|}
\hline Respondent & Discipline & Age/gender & Position \\
\hline Sanil & Physics & $43 / \mathrm{M}$ & Associate professor, research institute, India \\
\hline Raj & Cognition and mathematics & $35 / \mathrm{M}$ & Associate professor, research institute, India \\
\hline Maya & Applied mathematics & $40 / \mathrm{F}$ & Associate professor, research institute, India \\
\hline Malovika & Biochemistry and nutrition & $45 / F$ & Associate professor, India \\
\hline Aarthi & $\begin{array}{l}\text { Primatology, behavioural } \\
\text { ecology, } \\
\text { conservation biology }\end{array}$ & $35 / F$ & Associate professor, research institute, India \\
\hline Sandeep & Physics & $35-45 / M$ & University reader, UK \\
\hline Vipin & Materials & Early $40 \mathrm{~s} / \mathrm{M}$ & University reader, UK \\
\hline Govri & Physics & Late $40 \mathrm{~s} / \mathrm{F}$ & University research fellow, UK \\
\hline
\end{tabular}

TABLE 3

RESEARCH PARTICIPANTS (EARLY CAREER)

\begin{tabular}{|l|lcc|}
\hline Respondent & \multicolumn{1}{|c|}{ Discipline } & Age/gender & Position \\
\hline Vishnu & Biochemistry & $26 / \mathrm{M}$ & PhD student, India \\
Ashok & Genomes, DNA & $28 / \mathrm{M}$ & PhD student, India \\
Girish & Bioinformatics & $27 / \mathrm{M}$ & PhD student, India \\
Madhu & Nanotechnology & $27 / \mathrm{M}$ & PhD student, India \\
Manu & Microbiology & $32 / \mathrm{M}$ & PhD student, India \\
Rina & Biochemistry & $25 / \mathrm{F}$ & PhD student, India \\
Ajay & Nanotechnology & $32 / \mathrm{M}$ & Research scientist in \\
Amir & & & software firm, UK \\
Prakash & Nanotechnology & Early 20s/M & PhD student, UK \\
& Theoretical computer science & $35 / \mathrm{M}$ & PhD student, India \\
\hline
\end{tabular}


Only four of the 26 respondents were women. Whilst this is not an area that we will examine in depth in this paper, the issue of gender and the development of scientific careers is an important one that we have discussed elsewhere (Duberley and Cohen, 2010). Tables 1-3 provide a summary of our sample, arranged according to career stage. Interviews took place at respondents' places of work, and lasted between 1 and 2 hours. During the interviews, the scientists recounted their career stories, describing their experiences, both in India and overseas, their decisions about where to pursue their science (institution, sector and country), and their experiences of constraint, enablement and success. They also spoke of their aims and aspirations - scientific, career and with respect to life more generally - the significance of their Indian identities for their careers, and likewise about the ways in which their career experiences influenced their sense of Indian-ness. Mindful of social desirability effects that have been highlighted as a potential limitation of interview-based methods (Kvale, 1996), we took care to ask similar questions in different ways, probe respondents' explanations and justifications, and explore apparent contradictions and inconsistencies. Also, given that he himself had made career moves that were similar to those of many of our respondents, the Indian co-author was aware of this issue and was sensitive to familiar and well-rehearsed rationales. His insights into these issues facilitated a reflexive approach to the research process, in terms of both data collection and analysis.

Interviews were conducted in English, recorded and fully transcribed, and thematically coded using template analysis (King, 2004). Consistent with King's approach, this involved an iterative process in which the authors did a close reading of a sample of five transcripts, identifying emerging codes. This was followed by a discussion that led to refinement and clarification of the template. We then returned to the original sample of transcripts, applying the putative codes and making further adjustments. Through this process of "progressive focus ing"' (Hammersley and Atkinson, 1994), we established the template that we eventually used in analysing the remaining 21 transcripts. Having completed the process, we met to review our coding of another three transcripts to ensure consistency in our conceptualization of the codes and application of the template. Here again, the diversity of the authors' backgrounds and experiences enabled us to reflexively interrogate our emerging template.

\section{EMPIRICAL FINDINGS}

In the sections that follow, we present our findings in terms of the three research questions identified earlier.

\section{How did respondents account for their decisions to go abroad to pursue their} careers?

A striking feature of our data was scientists' accounts of the intense competition that characterizes contemporary, middle-class India. They linked this with the fundamental insecurity of life in India, which led to a willingness to do "whatever it takes to get ahead"'. In the follow ing extract, Sanj describes what he sees as the difference between India and the West in this respect:

The major difference with us Indians - us means exactly myself - was that we always, I mean in India, had this insecure feeling ... but when I travelled with my Dutch students [Sanj had lived in Holland] I felt they did not worry about anything because they're brought up in a very secure society which was developed after the Second World War. There is social welfare - they live in a golden age ...Whilst in India we were always thinking, "well, I have to study, I have to pass, I have to compete'. India is a competitive society and it is a kicking society. You cannot survive as mediocre. 
This desire to rise above the mediocre was a permeating feature of our data and all of our respondents saw career mobility as a route to career success. At the time of interview, 17 already had overseas experience and the remaining respondents had definite plans to go abroad. This imperative was explained in two key ways: first as providing access to prestigious research centres and people, and second as conforming to social norms. With respect to the resources issue, amongst our respondents there was a consensus that to succeed in science it was essential to work with people at the forefront of their field and in the most prestigious institutions - neither of which could be found in India. Raj, for example, explained how he had chosen to do his $\mathrm{PhD}$ in a Midwestern US university because at the time it was seen as a leading centre for research in his area. Interestingly, however, when he later discovered that this department was "on the way down" in the rankings, he moved to a more prestigious institution, where he worked with famous research leaders and got a second $\mathrm{PhD}$ in a different field.

On one hand, the importance of working with high-profile people in famous places was linked to material resources (e.g. "state of the art" laboratories). There was a common view that top research centres abroad would be better funded, enabling individuals to do higherquality, more exciting science, and thus to "grow" (which to our respondents meant upward progression). Many respondents bemoaned the bureaucracy of Indian science and the lack of resources in many scientific institutes. They also highlighted greater opportunities and financial support for engaging in more applied science abroad, given India's preference for highly theoretical work and the lack of value placed on links with industry.

International mobility was also seen to be important in terms of social capital, providing early career researchers with "exposure" to the wider scientific community. Such exposure was seen by respondents as fundamental not only to their own legitimacy, but also to their ability to access key scientific networks that were described as crucial to career success. Leaving India was partly to enable participation in such groups. Interestingly, s o m e of the networks that respondents highlighted as most influential consisted largely of Indian scientists. As Sandeep explained: "Cambridge was the physics hub for Indian scientists ... top academics were always visiting Cambridge and I met a lot of Indian physicists there and in that way it was important."

Similarly, many senior scientists, including Kirit, Sameer and Rajan, discussed how renowned Indian scientists, who had known about them through their various Indian scientific networks, had approached them and helped them to secure positions.

Regarding the second point, conforming to social norms, our respondents explained that as students embarking on scientific careers they had seen international mobility as important because their peer groups, families, communities and even future employers saw it as essential to the pursuit of career success. Amongst our respondents, this was uncontested. Going abroad was quite simply "what you did"': a key step on the socially ratified career path that the brightest young scientists followed. With respect to family and community expectations, Ajay vividly described the competitive nature of Indian society and the pressure families placed on young people to succeed:

... it was probably an ambition of our parents that the children should grow more and more and get exposure to what's going on world-wide, which is I think very evident in educated Indian families. They emphasise a lot on good education. I'm not saying the rest of the world doesn't, but probably led by mere peer pressure they have to do it because if your kid doesn't do it, your neighbour's kid will outshine you.

For burgeoning scientists, this invariably meant international mobility.

\section{How do relationships with India feature in respondents' talk about the development of their careers?}

Permeating our data were accounts of ongoing relationships with India and of a continuous movement of ideas back and forth between India and the West. Scientists spoke at length 
about their ambitions to stay at the forefront of their fields. However, a parallel theme emerging in the accounts of both UK and India-based repondents was the idea of making a contribution to India, particularly in terms of its scientific and economic infrastructure. For example, Raj explained his decision to leave his position in the United States (USA) to return to India:

In terms of larger things, staying in India meant being able to be around my family. Frankly, I think this must have played a role unconsciously but - a bigger role was played by the fact that I could make a difference here in a way that I can't in the US. Both because the field is new here but also institutional structures here [are] being set up.

From a UK perspective, Ajay spoke of his plans to set up an entrepreneurial scientific research institute in India in order to promote scientific disciplines that he sees as losing out in the current climate:

I'm looking for something else, and that something else is what my long-term objectives are - to set up some sort of an institute in India which would promote scientific research, applied research, taking scientific ideas to commercial reality and bring that focus back and encourage science and education in India [before it declines] - clearly because all the bright students are opting for software or engineering based subjects and no-one wants to get into Bachelors of Science and Physics.

These two extracts illustrate some interesting features of the data. First, respondents spoke of how transformations in India's economy enable infrastructural development and offer opportunities for increased contact with the West - opportunities in which UK-based scientists in our sample were keen to be involved. Linked with this is Ajay's wish to introduce early career scientists to more applied perspectives. He, and many other respondents, see this as crucial in a scientific environment that, as we noted above, has tended to privilege theoretical over applied research. However, at the same time Ajay and others were concerned that the burgeoning of opportunities in the information technology enabled sector was leading to an internal "brain drain" from core disciplines to IT and engineering. These respondents felt that they had an important role to play in promoting science and scientific careers to young people embarking on higher education and starting to make decisions about their future.

Notably, whereas some younger respondents sought to use their science to participate in and contribute to India's economic transformation, several older scientists in our sample explained how the wish to contribute was an enduring characteristic of Indian scientists who had moved back and forth between India and the West. Raj saw this as extending beyond science, to Indian intellectual life more generally:

Everybody I know who came back to India with these kinds of things in mind, we would be happy only if we really change the way of the intellectual climate here. That is the way I would say for most of us, we feel like 50 years before Independence saw an intellectual renaissance in India which managed to do certain things ... And many of us are concerned with what we can do not to revive that because that itself is time-bound ... but to ask what a new intellectual world will look like in India.

Scientists also talked extensively about the movement of knowledge and ideas that they depicted as dynamic and multidirectional. Indeed, respondents based both in India and the UK enthused about their international collaborations. For example, Raj spends 3 months each year at a US university campus in the USA, while fellow mathematician Maya noted: "Periodically I visit conferences or as a visiting professor I go to Europe or US universities ... so probably I can live with that instead of settling abroad.”

It is important to note that throughout our data set, developments in technology and air travel were seen to enable respondents' continued relationships with India. In what follows, 
Kirit describes how things have changed since his days as a student in the USA:

During my entire three and a half year stay in the US, I made just two phone calls to my father. On both occasions due to a bad connection, he didn't hear what I was saying and I could not make out clearly what he was saying or intending to say. We heard each other's voice and that was all. Otherwise I would write a letter every week and that would reach him some ten days later. That is all the communication we used to have. And there were always anxieties. It would take three days to get to Bangalore even by air. It's a different world today. Boys just take a bag as if they are going to shop and go to the US.

In the last line of this extract, his reference to what the "boys"' do, Kirit alludes to the importance of the social dimension of international mobility, highlighted in the first empirical section. Here as elsewhere, our data highlight the extent to which respondents appeared to develop their careers, including their ongoing relationships with India, according to group norms and patterns.

\section{How are Indian national /cultural identity commitments reflected in respondents' career accounts?}

The idea of enduring Indian values as influencing respondents' career thinking and action was a significant feature of our data. Respondents talked at length about how their Indian upbringing made them hard-working, competitive and committed to their employers. Furthermore, those of our respondents who had spent periods of time abroad spoke at length about their continued feelings of “Indian-ness". In our data this was described both in material terms - having Indian friends, eating Indian food and participating in cultural activities and rituals - and also as a more abstract feeling about who and what they were. The following series of extracts gives some sense of the depth and diversity of these responses:

If I'm by myself I still sort of yearn for Indian food or Indian music and I think these are very much part of yourself ... it's a psychological thing I believe, which is associated with your memory and your experiences in the past which you are unable to recreate. (Ajay)

You know a lot of Indians ... you always talk to each other and you sort of huddle amongst yourselves and things like that. So everywhere you go there is an Indian community [and an] identity. (Vipin)

It's fundamentally down to a way of life and I think it's more to do with certain basic qualities that I treasure as an Indian. (Sanj)

I'm still an Indian citizen and I think a large part of me is Indian. You know, it's not that I live with Indians or I interact with Indians every day but that part of my Indian identity is still there. (Sandeep)

[In response to a question about why he had returned home to India from the USA] ... and to a significant extent to come back to my country. That "my country" feeling was there. (Raj)

With respect to our interest in careers, this issue of Indian identity is important because it was seen to underpin the respondents' commitment to maintaining links with India, and the ways in which they creatively managed their careers in order to do so.

However, notwithstanding the prominence of Indian identity claims in our data, we would not wish to suggest that these were unitary or unproblematic. Some respondents, such as Amol, explained how when people return to India from abroad, they are no longer seen in the same way: "There are a number of software engineers from Pune (in India) who come 
here (to the UK) and go back. But then, it's a societal thing in India, people look at you and go, 'oh, he’s a non-resident Indian'. So they look at you in a different way.' The salience of others' identity attributions was likewise an issue for Govri, who had gone to the UK, returned to India and then gone back to the UK. At several points in her interview, she repeated that that while in the early days she was deeply troubled by being continuously cast as "other", it no longer bothered her:

And then when I came back here and decided to stay, then at that point I probably still had some problems with my identity and who I was, but for some reason now I don't feel that so acutely. In a lot of situations I forget who I am. For instance, I would forget in a lot of situations that I probably stood out and was different. I forget that. People always call you Indian. They'll say, “that Indian person” ... I mean I can’t say that I can sort of label my identity and tell you what I think I am. I can't do that because it's all so complicated and such a complex sort of situation, but I'm not troubled by the fact that I'm different or I'm labelled as someone different. I'm not troubled by that any more. I used to be, but I'm not now.

What particularly stood out in Govri's account was a sense of national /cultural identity construction as an ongoing and contested process, one that she saw as having significant implications for her experiences of career, and especially her career progression. While she had always been able to find jobs, she felt that her "outsider" status both in the UK and India had impeded her upward movement.

Alongside extensive discussion of Indian values and identities, eight respondents also introduced another sort of identity claim that they described as a feeling of "global citizenship". This notion was used to convey a number of different aspects of respondents' experience. For some, such as Ajay, it highlighted a certain cultural literacy and ability to “perform”: "However much I live in the UK, I am still an Indian ... It is very contradictory. Now to anyone externally that looks at me I can be a global citizen because when I dine with friends and when I go out with them I'm happy to sort of mix and mingle and understand different things."

For Ajay, being a global citizen did not seem to compromise his sense of Indian-ness, nor did it appear to offer him an alternative identity status. Rather, he described it in behavioural terms. His cultural literacy enabled him to participate in a whole range of activities across a number of social contexts, in both professional and personal spheres. With respect to careers, seeing himself as a global citizen seemed to provide Ajay (and others in the sample) with a range of choices, not only with respect to national/cultural setting, but also in terms of occupational sector. Likewise, Raj explained that because of the extent of his cultural capital he was able to slip into American society, in stark contrast to other migrant groups: "I can easily pass as a native. If I got to the US tomorrow I would be a high status individual there and I know how to move around. I don't have the immigrant experience of not belonging. That's just not there.’'

Here, global citizenship is depicted as a social phenomenon in which certain high-status people and groups are warmly welcomed by and succeed in blending into the societies they choose to join. They are respected and valued - their right to be there is not in question.

However, others spoke of their global citizenship not in performative terms to convey their cultural literacy and ease in moving across contexts, nor structurally to highlight Indian scientists' privileged position but, rather, to connote feelings of control, autonomy and success. As Sanj explained: "I feel very, very good now because now I can move anywhere and that feeling is very nice, and the confidence that I've built up with this passage of time, that is very nice as well. Personally feel I belong everywhere. Now this is my personal feeling these days and probably, it may change after a week." At the time of interview, Sanj was due to start work on a prestigious research grant that he had recently been awarded. Therefore, for Sanj, being a global citizen was always precarious, contingent oncareer success. As he explained: "[feeling like a global citizen] depends on my mood [laughter]. The positive 
factor comes when you have success. The negative factor comes when you feel that things are not moving as you want to.",

Although respondents talked a lot about global citizenship and many saw themselves in these terms, as the following quote by Sunil reiterates, this was not always a straightforward or uncontested description:

I personally view myself as a global citizen. I frequently sit on international boards of journals and all that and I'm, the British, you know, representative ... Having said that, for example I recently got to speak in India. That's the first time I've ever been speaking in India and invited to, and I did actually feel good about it. I think it did feel good going back, [but] I think I did feel at times that I didn't actually belong there and at the same time I actually felt a certain affinity too. So it's difficult to articulate.

For Sanil, living abroad had been an opportunity to develop new ways of being. Upon returning home to India, he did not experience these as competing with his sense of Indian- ness, but as existing alongside one another in a complex hybrid:

You find a lot of people who can’t wait long enough to shed themselves of their Indian-ness ... I'm very comfortable in being a citizen of the world. But not for show, it's not a label I wish to wear. So one should be really honest about what your different identities are, sort of, understand where your inspirations come from, and be really true to it ... it's good to have a good feeling about your place of origin and your country, and your global culture.

Here, the issue was not so much about "performing" identity, as was the case with Ajay, but instead about identity commitments. Both recurred in the accounts that we heard - sometimes, indeed, within a single individual's career story.

\section{CONCLUDING DISCUSSION}

In this paper, we have explored how Indian scientists experience international mobility, examining why such movement is seen to be important in the development of a scientific career; the nature of scientists' continuing relationships with India in the pursuit of their careers; and the ways in which issues of national/cultural identity intersect with scientists' career experiences.

Applying Vertovec's (1997) framework to our findings, we would argue that Indian scientists could be considered a career diaspora, highlighting three important features that are under-represented in the extant literature: career as a social form and process; the notion of the career as a cultural product; and the interrelationship of career and dynamic national /cultural identities as ongoing facets of international careers.

On the basis of the evidence presented, we would argue that considering career as a social form and process highlights two important aspects of career thinking and enactment that are obscured in more individualistic analyses. First, our findings demonstrate the awareness amongst these scientists of a pre-existing “diasporic path”. As highlighted above, the scientists in our study were deeply aware of a socially ratified route that provided them with a clear avenue into research internationally. This path was sanctioned by families and communities, and was believed to offer a means of creating security in a volatile social and economic context. 
A notable aspect of this diasporic path relates to the myth of return. As we discussed earlier, while some diasporic scholars have argued that this is a central characteristic of the concept of diaspora itself, others (Ackers and Gill, 2008; King, 2002; Koshy and Radhakrishnan, 2008) have argued that for neo-diaspora groups such as the highly skilled scientists in our study, the myth of return is open to question. Based on the findings of this research, we would support this alternative view. Although ten scientists in our sample had lived in the West for more than 5 years and at the time of interview had no intention of returning to India on a permanent basis, they nevertheless maintained strong links with India and discussed their desire to use their science to make a contribution. For some, this related to their disciplinary interests and the development of India's scientific infrastructure, while others aimed to exploit their commercial acumen for the benefit of India's economic activity. With respect to the myth of return, in light of such data we would suggest that the diasporic career path offers possibilities for continued interaction and engagement with India that are no longer dependent on a permanent move 'back home'.

On a material level, exposure to the most prestigious institutions around the world was seen as enabling scientists to access important material, social and cultural resources, providing them not only with credibility and status, but also opportunities for further career advancement. This awareness and utilization of the global network (Meyer, 2001) meant that the existing diaspora had a profound effect on respondents' career ambitions. However, like Ackers and Gill (2008), we would not wish to suggest that this impact was uniform. Whilst our analysis highlights the importance of the social dimension of scientists' career development, this is not to suggest that they were following a totally determined route. Instead, they were making career choices depending partly on this well-trodden diasporic path, but also on the nature of their science, the opportunities it afforded and their own scientific curiosity and ambition.

Our second contribution relates to the notion of career in general, and the diasporic career in particular, as cultural products (Vertovec, 1997). For Vertovec, this dimension relates to the exchange and transformation of ideas and artefacts that inevitably result from the diasporic patterns of movement. Far from being free-floating entities that operate over and above the contexts in which they are enacted, our data depict careers as situated products of these dynamic contexts. To think about Indian scientists' careers in this way alerts us to facets such as India's educational and scientific infrastructure, its economic transformation and the intense competition that characterizes contemporary Indian society, as well as its fundamental precariousness - aspects reported in the data analysis - that were seen to significantly shape the careers of our respondents. For those who settled abroad, the experience of migration continued to impact on the kinds of careers they imagined, and sought to develop. The diasporic career accounts that we heard were full of the kind of "back and forth transferences, mutual influences, new contestations, negotiations and constant transformations" highlighted by Vertovec (1997: 19). Our point here is that the way in which individuals think about their careers and the decisions they make are inseparable from these landscapes. Careers do not look the same everywhere - they are inscribed and interpreted through cultural frames of reference (Baruch and Budhwar, 2006; Mkhize and Frizelle, 2000).

However, we would also argue that the science that is created in the course of these careers can be considered a diasporic product. As evidenced in our findings, a permeating theme was respondents' desire to use their science to make a contribution to India. For some, this related to their disciplinary interests and the development of India's scientific infrastructure, while others aimed to exploit their commercial acumen and contacts to contribute to India's economic activities. Our work thus supports that of other migration scholars (Ackers and Gill, 2008; Meyer, 2001; Sahoo, 2006) who suggest that highly skilled expatriate networks can use their knowledge to make a positive impact in their countries of origin. Here, recent 
work on "brain drain" and its reconfiguration as "brain circulation"' (Meyer, 2001; Singhal and Rogers, 2001; Varma, 2007) has a clear resonance. Notably, our data highlight how science itself can be shaped by the movement of scientists around the globe and the increased potential for collaboration that such movement fosters.

Finally, on the basis of the accounts we heard, we propose that for mobile career actors the relationship between national/cultural identity and career is a significant aspect of their experience. Respondents saw being Indian as central to the way in which they thought about and developed their careers: not only in terms of underpinning values and norms, but also maintaining links with India, which was a key feature of the career trajectories they chose. For some, such as Govri, international career mobility was experienced as a challenge to a coherent sense of identity, in particular with respect to how they were cast as "other" by both outsiders and insiders. Others, however, talked about how they were able to maintain their Indian-ness whilst also embracing what they called “global citizenship”. Thus our data vividly illustrate the argument put forward by Glick Schiller et al. (1996) concerning transmigrants' “fluid and multiple identities"' (p. 11). From this perspective, becoming a global citizen appears to involve joining a new, highly agentic group, but without having to give up the old one. Many respondents thus seemed to maintain hybrid identities, enabling them to participate in global careers and engage fully in life within their adopted countries, whilst retaining a coherent sense of themselves as Indians. Deeply rooted in their pasts, in the stories that we heard this sense of being Indian was constructed and reconstructed by respondents as part of an ongoing narrative, important to which is the fulfilment of responsibilities to their families, Indian science and Indian society more generally. Our data leads us to believe that such hybridity can also lead to identity and career challenges: about who one is, where one belongs, to what country one's responsibilities lie, and about where and how to build a career that honours these sometimes conflicting imperatives.

From a careers perspective, on the basis of our data we would argue that considering oneself a global citizen can be seen as a powerful form of career capital (Ielliatchitch et al., 2003). A sign of cultural literacy (Benet-Martinez et al., 2002), it was an identity that demonstrated their ability to "perform" appropriately across diverse national /cultural contexts. As global citizens they could live anywhere, understand the rules of whatever context they were in, blend in. Significantly, the notion of global citizenship was also a sign of status, a sign that scientists were different from "immigrants", with whom our respondents felt they had little in common. This reinforces an important point raised by Anthias (1998), that diasporic populations should not be homogenized. The fact that our respondents were part of a highly educated, elite group was important to them, and clearly differentiates their experiences of migration from those of other less-privileged groups. They described their affiliation with other important people as a key career resource, and this can be seen as both a driver and an outcome of career success. However, the sense of individual agency that permeated respondents' talk about global citizenship was underpinned by a certain precariousness. Respondents said that they felt like global citizens when they were doing well, but were aware that such feelings were only ever temporary, contingent and thus fragile.

In conclusion, this study has enabled us to develop our understanding of the interrelationship between the social in terms of diaspora and the individual in terms of career decisionmaking and enactment. We would argue that our approach has elucidated the complex interplay between career development, migration and issues of national /cultural identity and affiliation. However, we are at the same time aware of the limitations of our study. Whilst small, in-depth studies such as this give insight into peoples' career experiences, further work is needed to explore the applicability of these ideas. In particular, it is important to compare the experiences of people from different ethnic groups and national/cultural contexts (in terms of both country of origin and host countries), and from diverse occupations. It 
would also be valuable to undertake longitudinal research tracking individuals' careers over time as they make international moves.

Ackers, L.

\section{REFERENCES}

2005 “Moving people and knowledge: scientific mobility in the European Union”, International Migration, 43(5): 99-131.

Ackers, L., and B. Gill

2008 Moving People and Knowledge: Scientific Mobility in an Enlarging European Union, Edward Elgar, London.

Anderson, A.

2001 The Powers of Distance: Cosmopolitanism and the Cultivation of Detachment, Princeton University Press, Princeton, NJ.

Anthias, F.

1998 “Evaluating diaspora: beyond ethnicity”, Sociology, 32(3): 557-580.

Ballard, R., and D. Pardesh

1994 The South Asian Presence in Britain, Hurst, London.

Balram, $\mathrm{P}$.

2001 “Redirecting migrations: reversing the brain drain”, Current Science, 80(7): 805-806.

Baruch, Y., and P. Budhwar

2006 “Career practices: comparing India vs UK”, International Business Review, 15(1): 84-101.

Baruch, Y., P. Budhwar and P. Khatri

2007 "Brain drain: the inclination of international students to stay abroad after their studies", Journal of World Business, 42: 99-112.

Benet-Martinez, V, J. Leu, F. Lee and M. Morris

2002 "Negotiating biculturalism: cultural frame switching in biculturals with oppositional versus compatible cultural identities”, Journal of Cross Cultural Psychology, 33(5): 492-516.

Brah, A.

1996 Cartographies of the Diaspora, Routledge, London.

Carr, S., K. Inkson and K. Thorn

2005 "From global careers to talent flow: reinterpreting 'brain drain”,, Journal of World Business, 40: 386-398.

Cassell, C., and G. Symon (Eds)

2004 Essential Guide to Qualitative Methods in Organizational Research, SAGE Publications, London.

Cohen, R.

1997 Diasporas, UCL Press, London.

2008 Diasporas: An Introduction, second edition, Routledge, London.

Collings, D., H. Scullion and M. Morley

2007 "Changing patterns of global staffing in the multi-national enterprise: challenges to the conventional expatriate assignment and emerging alternatives”, Journal of World Business, 42: 198-213.

Dickmann, M., and H. Harris

2005 “Developing career capital for global careers”, Journal of World Business, 40(4): 399-408.

D’Mello, M., and S. Sahay

2007 “' 'I am kind of a nomad where I have to go places and places': understanding mobility, place and identity in global software work from India”, Information and Organization, 17(3): 162192.

Duberley, J., and L. Cohen

2010 "Gendering career capital: an investigation of scientific careers”, Journal of Vocational Behavior, 76: 187-197. 
Duberley, J., L. Cohen and E. Leeson

2007 "Entrepeneurial academics: developing scientific careers in changing university settings", Higher Education Quarterly, 61(4): 479-497.

Florida, R.

2004 The Rise of the Creative Class: And How It's Transforming Work, Leisure, Community and Everyday Life, Basic Books, London.

Glick Schiller, N., L. Basch and C. Blanc-Szanton (Eds)

1996 Toward a Transnational Perspective on Migration, New York Academy of Sciences, New York.

Halsall, R.

2009 "The discourse of corporate cosmopolitanism”, British Journal of Management, 20: S136-S148.

Hammersley, M., and P. Atkinson

1994 Ethnography: Principles in Practice, second edition, Routledge, London.

Ielliatchitch, A., W. Mayrfhofer and M. Meyer

2003 "Career fields: a small step towards a grand theory?” International Journal of Human Resource Management, 14: 728-750.

Iredale, $\mathrm{R}$.

2001 “The migration of professionals: theories and typologies”, International Migration, 39(5): 7-26.

Iredale, R., and R. Appleyard

2001 “International migration of the highly skilled: an introduction”, International Migration, 39(5): 3-6.

Kanter, R.

1995 World Class: Thriving Locally in the Global Economy, Simon and Schuster, London.

Kapur, D.

2004 "Ideas and economic reforms in India: the role of international migration and the Indian diaspora’, India Review, 3(4): 364-384.

King, $\mathrm{N}$.

2004 “Using interviews in qualitative research”, in C. Cassell and G. Symon (Eds), Essential Guide to Qualitative Methods in Organizational Research, SAGE Publications, London: 11-22.

King, R.

2002 “Towards a new map of European migration”, International Journal of Population Geography, 8: 89-106.

Koshy, S., and R. Radhakrishnan (Eds)

2008 Transnational South Asians: The Making of a Neo-Diaspora, Oxford University Press, Oxford.

Kvale, S.

1996 InterViews: An Introduction to Qualitative Research Interviewing, SAGE Publications, London.

Mahroum, S.

2001 “Europe and the immigration of highly skilled labour’, International Migration, 39(5): 27-42.

Meyer, J.

2001 “Network approach versus brain drain: lessons from the diaspora”, International Migration, 39(5): 91-110.

Mkhize, N.J., and K. Frizelle

2000 “Hermeneutic-dialogical approaches to career development: an exploration”, South African Journal of Psychology, 30: 1-8.

Narasimha, R.

2008 "Science, technology and the economy: an Indian perspective’, Technology in Society, 30 (3-4): 330-338

Nilekani, N.

2008 Imagining India: Ideas for the New Century, Penguin, London.

Pieperl, M., and K. Jonsen

2007 "Global careers”, in H., Gunz and M., Pieperl (Eds), Handbook of Career Studies, SAGE Publications, London. 
Raghuram, P.

2004 'Migration, gender, and the IT sector: intersecting debates', Women's Studies International Forum, 27(2): 163-176.

Sahoo, A.K

2006 “Issues of identity in the Indian diaspora: a transnational perspective”, Perspectives on Global Development and Technology, 5(1-2): 81-98.

Singhal, A., and E.M. Rogers

2001 India’s Communication Revolution: From Bullock Carts to Cyber Marts, SAGE Publications, New Delhi.

Varma, R.

2007 "Changing borders and realities: emigration of Indian scientists and engineers to the United States’, Perspectives on Global Development and Technology, 6: 539-556.

Vertovec, S.

1997 "Three meanings of diaspora exemplified among South Asian religions”, Diaspora, 6(3): 277-300.

Williams, A.M., V. Balaz, and C. Wallace

2004 “'International labour mobility and uneven regional development in Europe’, European Urban and Regional Studies, 11(1): 27-46.

Wodak, R., R. DeCillia, M. Reisigl and K. Liebhart

1999 The Discursive Construction of National Identity, Edinburgh University Press, Edinburgh. 